\title{
Varying Tolerance to Glyphosate in a Population of Palmer Amaranth with Low EPSPS Gene Copy Number
}

\author{
Neal D. Teaster, Robert E. Hoagland \\ US Department of Agriculture-Agricultural Research Service, Crop Production Systems Research Unit, Stoneville, USA. \\ Email: bob.hoagland@ars.usda.gov
}

Received October $1^{\text {st }}, 2013$; revised November $2^{\text {nd }}, 2013$; accepted November $19^{\text {th }}, 2013$

Copyright (C) 2013 Neal D. Teaster, R. E. Hoagland. This is an open access article distributed under the Creative Commons Attribution License, which permits unrestricted use, distribution, and reproduction in any medium, provided the original work is properly cited.

\begin{abstract}
A Palmer amaranth population (seeds collected in the year 2000; Washington Co., MS) suspected to be susceptible to glyphosate was examined as a population and as individual plants and found to exhibit varying tolerance or resistance to glyphosate. Whole plant spraying of glyphosate $\left(0.84 \mathrm{~kg} \cdot \mathrm{ha}^{-1}\right)$ to the population revealed that approximately $40 \%$ of this population were resistant to glyphosate and an $\mathrm{LD}_{50}$ of $0.75 \mathrm{~kg} \cdot \mathrm{ha}{ }^{-1}$ was determined. Spray application of glyphosate indicated that some plants displayed varying degrees of resistance 14 days after treatment. Initial tests using leaf disc bioassays on 10 individual plants selected randomly from the population, allowed characterization of glyphosate resistance using both visual ratings of injury and quantitative measurement via chlorophyll content analysis. After initial bioassays and spray application, five plants with a range of tolerance to glyphosate were selected for cloning so that further studies could be accomplished on these individuals. Q-PCR analysis of these clones showed that resistance was not due to elevated EPSPS gene copy number. Shikimate levels were lower in the resistant and higher in the susceptible clones which correlated with varying degrees of resistance demonstrated in bioassays and spray application of glyphosate of these clones. Results demonstrate that individuals in a population can vary widely with respect to herbicide resistance and suggest that uptake, translocation, sequestration, metabolism or altered target site may contribute to the resistance in some individuals of this population.
\end{abstract}

Keywords: Amaranthus palmeri; EPSPS (5-Enolpyruvylshikimate-3-phosphate Synthase); EPSPS Gene Copy Number; Glyphosate-Resistance; Herbicide Tolerance; Population Variance; Pigweed

\section{Introduction}

The broad-spectrum, systemic herbicide glyphosate $(\mathrm{N}$ phosphono-methylglycine) was introduced in the early 1970s and about twenty years later (1990s) genetically engineered glyphosate-resistant crops became available. Presently glyphosate is not only widely used on non-agricultural areas, but as a burn-down agent of cover crops and to control various weeds on millions of acres of glyphosate-resistant soybeans, cotton and corn. Initially, most weeds were efficiently controlled with glyphosate, but as early as 1997, glyphosate resistant weeds were reported and presently there are about 24 species reported to be resistant to glyphosate [1]. The glyphosate resistance problem has been exacerbated by its increased use for weed control in genetically modified crops such as corn, cotton and soybeans [2]. These resistant weed biotypes exist in nearly all countries of the world creating major problems in rangelands, natural settings and rightsof-way.

Glyphosate-resistance in Palmer amaranth (Amaranthus palmeri) was first reported in Georgia [3] and following this event, glyphosate resistant Palmer amaranth was discovered in several other southern states [4,5]. Glyphosate-resistant Palmer amaranth is now widespread in the southern U.S. where it has been deemed one of the most troublesome weeds of agronomic crops [6]. Palmer amaranth [dioecious plant (either male or female)] can grow tall, has a rapid growth rate [7] and produces abundant seeds [8,9]. These traits render it extremely competitive with crop plants and the management of glyphosate-resistant Palmer amaranth is very challenging with the herbicide technology presently available [10-12].

The mode of action of glyphosate in plants is competitive inhibition of 5-enolpyruvylshikimate-3-phosphate 
synthase (EPSPS; E.C. 2.5.1.19), a chloroplastic enzyme of the shikimate pathway [13-15]. Inhibition of EPSPS causes depletion of aromatic amino acid (phenylalanine, tyrosine and tryptophan) pools, and shikimate levels increase after glyphosate application to susceptible plants $[16,17]$.

The major resistance mechanism in glyphosate-resistant Palmer amaranth has been reported as elevated copy number of the EPSPS gene [18]. This high level of EPSPS gene copy number allows synthesis of sufficient EPSPS to promote aromatic amino acid production even after exposure to glyphosate. Since elevated EPSPS gene copy number is inherited, rapid spread of resistance can occur by pollen movement [18]. Pollen movement of up to 1000 feet from resistant male plants to susceptible female Palmer amaranth plants has been demonstrated [19]. Other mechanisms of glyphosate resistance include target site mutations, and altered translocation [20].

Weeds possess immense genetic diversity. Although individual plants from a population of a given weed species may appear similar, high genetic variability at the molecular level of individuals from a localized area or among populations from different locations may exist. Conversely, plants of the same species may possess obvious outward physical differences. Since Palmer amaranth is distributed over a large geographic area, major differences (morphological and molecular) among plant sources or biotypes may be present. Thus characterization of growth characteristics and molecular traits among these populations are important in the full understanding of the development, competitiveness, spread, and control of resistant weeds. A wide range of tolerance levels to glyphosate using leaf disc bioassays of numerous Palmer amaranth plants has been observed [21,22]. Recently, preliminary studies on seedlings of a glyphosate susceptible population of Palmer amaranth from seeds collected in 2000 in Washington County, Mississippi (WC) demonstrated a range of tolerance to glyphosate in leaf disc bioassays. To further characterize this population the objectives were 1) to use bioassays and spray application of seedlings to further characterize the variation in glyphosate tolerance; 2) correlate EPSPS gene copy number of individual plants with glyphosate tolerance; and 3) evaluate shikimate accumulation in response to glyphosate exposure. To accomplish this, groups of seedlings from the seed population were selected for propagation by cloning so that long term studies could be carried out on cloned plants that maintain unaltered genetic traits.

\section{Materials and Methods}

\subsection{Sources of Seeds and Chemicals}

Glyphosate (99.8\% pure, free acid) was obtained from
Chem Service (Chem Service, Inc., West Chester, PA). All other chemicals were reagent grade or higher purity. Seeds were obtained from field-grown plants as follows: Palmer amaranth seeds were collected from plants along a roadside in Washington County, MS in the year, 2000.

\subsection{Culture of Plant Seedlings}

Seeds of the Palmer amaranth source were planted in a commercial potting mix Jiffy-mix (Jiffy Products of America, Inc., Batavia, IL 60510) contained in plastic trays $(12 \mathrm{~cm}$ by $12 \mathrm{~cm})$. These trays were placed into larger sub-irrigated trays placed on greenhouse benches. Greenhouse temperatures ranged from $28^{\circ} \mathrm{C}$ to $32^{\circ} \mathrm{C}$ with $40 \%$ - 90\% relative humidity (RH). The photoperiod was $12-14 \mathrm{~h}$ with $1650 \mu \mathrm{Em}^{-2} \cdot \mathrm{s}^{-1}$ photosynthetically active radiation measured at midday with a light meter (LICOR, Inc., Lincoln, NE). The plants were thinned about one week after emergence ( $6-8$ per tray) and the young seedlings were fertilized with Miracle-Gro (The Scotts Company LLC, Marysville, OH) on a weekly cycle. Two weeks after emergence, plants were selected and transplanted into planting trays $(12 \mathrm{~cm}$ by $12 \mathrm{~cm})$ containing potting mix (described above). A density of 5 plants (4 to 5 leaf stage) per tray was used. Plants were grown to appropriate age for testing.

\subsection{Plant Cloning}

To test and characterize individuals from this population in a variety of tests over a long time period, selected individual parent plants were cloned as described elsewhere [22]. Briefly, excised petioles from branch points ( $\sim 10-20 \mathrm{~mm}$ long) of mature plants were immediately placed in deionized water. Each excised plantlet was removed from the water, blotted (absorbent paper towels), the cut end coated with rooting hormone powder (Hormex; 1.6\%) (Brooker Chemicals, Hollywood, CA), and planted in moistened vermiculite/peat/loam mixture contained in plastic trays $(6 \mathrm{~cm} \times 14 \mathrm{~cm})$. The planted cuttings ( 8 to 10 plantlets per tray) were maintained at $21^{\circ} \mathrm{C}$ $-23^{\circ} \mathrm{C}$ under low continuous light $\left(\sim 150 \mu \mathrm{E} \cdot \mathrm{m}^{-2} \cdot \mathrm{s}^{-1}\right)$ for 6 to 7 days to allow root initiation and growth, and then transferred to a greenhouse $\left(28^{\circ} \mathrm{C}-34^{\circ} \mathrm{C}\right.$, a $14 / 10$ day/ night cycle at $\sim 1650 \mu \mathrm{E} \cdot \mathrm{m}^{-2} \cdot \mathrm{s}^{-1}$ during the day) or growth chamber at similar environmental conditions. Plants propagated by this method were grown to the desired growth stage and then used in various tests.

\subsection{Spray Application of Glyphosate to Plants}

Glyphosate spray treatments were applied using a track spray system equipped with mobile nozzles (8002E nozzles) (Generation III Research Sprayer, DeVries Manufacturing; Hollandale, MN) delivering $187 \mathrm{~L} \cdot \mathrm{ha}^{-1}$ at 190 $\mathrm{kPa}$ to Palmer amaranth plants averaging $15 \mathrm{~cm}$ (five to 
seven leaf growth stage). Glyphosate at $0,0.05,0.17$, $0.32,0.53$ and $0.84 \mathrm{~kg} \cdot \mathrm{ha}^{-1}$ was applied to random selections of seedlings ( 5 per set and 4 replicates) grown from the general seed population (see seed source above) and to a set of selected cloned plants exhibiting a range of susceptibilities to glyphosate as measured in leaf disc bioassays [21]. A visual health rating was conducted at multiple time points ( 0 time, and at $24 \mathrm{~h}$ intervals) and each plant in the study was tracked and assayed over a period of 14 days. Rating scale: $7=$ no effect, $6=$ slight wilting, $5=$ moderate wilting, $4=$ severe wilting, $3=$ slight necrosis, $2=$ moderate necrosis, $1=$ severe necrosis, $0=$ dead.

\subsection{Leaf Disc Bioassay for Tolerance to Glyphosate}

Discs were cut from plant leaves using a cork borer (4 $\mathrm{mm})$ and placed in 12-well micro-titer plates with each well containing 3 discs and $2.5 \mathrm{ml}$ deionized $\mathrm{H}_{2} \mathrm{O}$ (control), or solutions of various concentrations $(0,0.25,0.50$ and $1.0 \mathrm{mM}$ ) of glyphosate as described earlier [21]. Plates containing leaf discs were placed under continuous light $\left(150 \mu \mathrm{E} \cdot \mathrm{m}^{-2} \cdot \mathrm{s}^{-1}\right)$ in an environmental chamber at $28^{\circ} \mathrm{C}$ for $96 \mathrm{~h}$. Each treatment was visually rated for injury (chlorosis and necrosis) at $24 \mathrm{~h}$ intervals utilizing a rating scale of 0 to 10 , where $10=$ no injury/good health and $0=$ total chlorosis (mortality). Injury was quantified by determining chlorophyll content in discs $96 \mathrm{~h}$ after treatment as described below.

\subsection{Chlorophyll Extraction and Quantification}

Chlorophyll content in the leaf disc bioassays above was used as a measure of injury caused by glyphosate at various concentrations and exposure times. The pigment was extracted with dimethyl sulfoxide and quantitatively determined spectrophotometrically $[23,24]$ using a NanoDrop $^{\mathrm{TM}}$ spectrophotometer (Thermo Scientific, Wilmington, DE) [25].

\subsection{Shikimate Assay after Exposure to Glyphosate at Various Concentrations}

Shikimate accumulation relative to glyphosate dose-responses was carried out in assays using 96-micro-titer well plates as outlined previously [26]. Discs from each clone (1 disc per well) were incubated in $1.0 \mathrm{ml}$ ammonium phosphate $(10 \mathrm{mM})$ plus Tween 80 surfactant $(0.1 \% ; \mathrm{v} / \mathrm{v})$ containing glyphosate $(0$ to $100 \mu \mathrm{M})$. After leaf-discs were wetted and submersed the plates were placed under fluorescent lights $\left(150 \mu \mathrm{E} \cdot \mathrm{m}^{-2} \cdot \mathrm{s}^{-1}\right)$ for $24 \mathrm{~h}$ at $22^{\circ} \mathrm{C}-25^{\circ} \mathrm{C}$. Following incubation, plates were immediately frozen and stored at $-20^{\circ} \mathrm{C}$ pending assay for shikimate. The frozen plates were removed from the freezer, allowed to thaw at room temperature, and 0.25 $\mathrm{ml}$ of $1.25 \mathrm{M} \mathrm{HCl}$ was added to each well, and then incubated at $60^{\circ} \mathrm{C}, 15 \mathrm{~min}$. A $25 \mu \mathrm{L}$ aliquot of the $0.25 \mathrm{M}$ $\mathrm{HCl}$ extract was pipetted into each of three wells of a micro-titer plate so that three replicate extract samples were assayed per clone. Then $100 \mu \mathrm{L}$ periodate: metaperiodate $(0.25 \%$ each; $\mathrm{v} / \mathrm{v})$ was as added to each well and the plate incubated at $37^{\circ} \mathrm{C}, 40 \mathrm{~min}$. This reaction was quenched by adding $100 \mu 1 \mathrm{NaOH}(0.6 \mathrm{M}): \mathrm{Na}_{2} \mathrm{SO}_{4}$ $(0.22 \mathrm{M})$ solution to each well and the optical density $(380 \mathrm{~nm})$ of each well determined using a plate reader (BioTek Instruments, Inc., Winooski, VT). High purity shikimate at a range of concentrations was utilized to prepare a standard curve. Data were analyzed by analysis of variance of fixed effects with differences presented as Least Squares Means (Software, Statistical Analysis Systems $^{\circledR}$, Version 9.1, SAS Institute, Inc., SAS Campus Drive, Cary, NC).

\subsection{Q-PCR Analysis}

DNA was isolated from fresh leaves of Palmer amaranth according to a modified method of the DNeasy Plant Mini Kit (QIAGEN Inc., Valencia, CA), quantified spectrophotometrically by means of a NanoDrop ${ }^{\mathrm{TM}} 2000 \mathrm{C}$ and analyzed for quality (lack of fragmentation or degradation) using gel-electrophoresis. Quantitative PCR was conducted using gene specific primers for EPSPS, EPSPSF (5'-CAACAGTTGAGGAAGGATCTG-3', EPSPSR (5'-CAGCAAGAGAGAATGCCAT-3') and acetolactate synthase (ALS), ALSF (5'-GCTGCTGAAGGCTACGCT-3'), ALSR (5'-GCGGGACTGAGTCAAGAAGTG-3') [18] and primer efficiency was determined [27]. EPSPS genomic copy number was quantified relative to the low copy control ALS gene, with known monogenic inheritance in other Amaranthus species [28]. Relative copy number in each plant was determined using the formula for threshold cycle calculated by the $\left(2^{-\Delta \Delta \mathrm{Ct}}\right)$ method [27].

\section{Results and Discussion}

\subsection{Tests of General Plant Population}

Initial tests on the susceptibility of seedlings from this population, sprayed with several rates of high purity glyphosate, indicated increasing growth reduction and injury effects as the glyphosate rate increased (Figure 1). This typifies the variance of this population as especially noted at the highest glyphosate rate $\left(0.84 \mathrm{~kg} \cdot \mathrm{ha}^{-1}\right)$, that depicts one plant with reduced growth (but still viable), and a second plant with extreme wilting, chlorosis and necrosis. Similar variation in plant response was also found in other treatment rates $\left(0.32-0.53 \mathrm{~kg} \cdot \mathrm{ha}^{-1}\right.$ ) (not depicted in photo). Average health ratings (4 replicates of 5 plants each) of Palmer amaranth at 1, 4, 8 and 14 days after treatment (DAT) with spray application of gly- 
phosate at five rates and an untreated control (Figure 2). The highest herbicide rate applied was a recommended field rate of $0.84 \mathrm{~kg} \cdot \mathrm{ha}^{-1}$. Generally, herbicide injury increased with increasing glyphosate rate and time. Essentially no effect was noted at 1 DAT at any of the rates used, but at 4 DAT some plants in the population began to exhibit wilting, while others exhibited no visual symptoms. However at 8 DAT, most (but not all) plants showed some effects (wilting and/or early signs of chlorosis), and at the higher glyphosate rates, necrosis was evident in the more susceptible plants. At 14 DAT a range of effects were found including dead plants, severe necrosis and wilting, but even at the highest rates a few plants showed regenerative growth. This indicates some degree of recovery, and perhaps the ability to survive. Hence these plants are more resistant than other plants from the general population.

The percentage of surviving Palmer amaranth plants

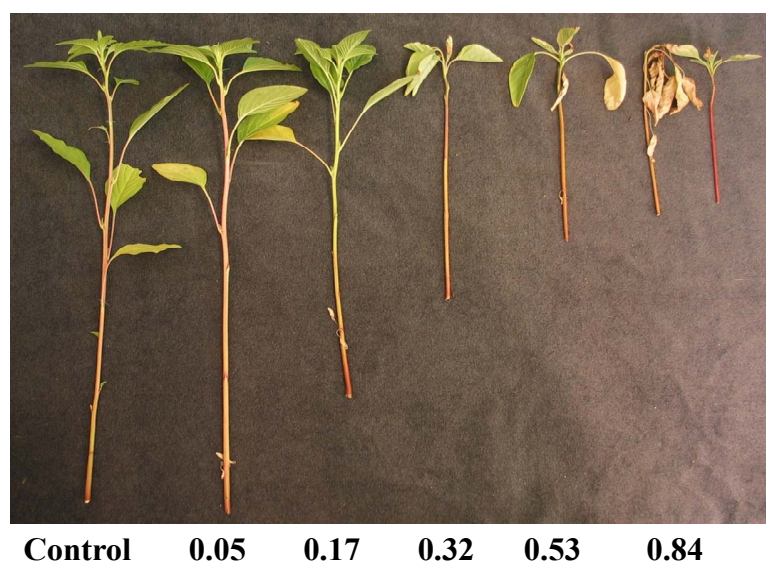

Glyphosate application rate $\left(\mathrm{kg} \mathrm{ha}^{-1}\right), 14$ DAT

Figure 1. Effects of several rates of glyphosate spray application to a population of Palmer amaranth plants, 14 days after treatment (DAT).

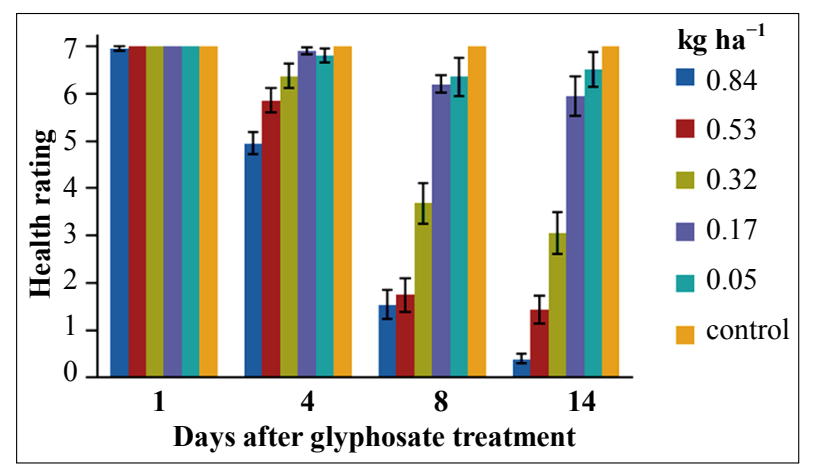

Figure 2. Health ratings of Palmer amaranth plants from a population at 1, 4, 8 and 14 DAT after spray application of glyphosate at various rates. Rating scale: $7=$ no effect, $6=$ slight wilting, $5=$ moderate wilting, $4=$ severe wilting, $3=$ slight necrosis, $2=$ moderate necrosis, $1=$ severe necrosis, 0 $=$ death/mortality. Error bars represent \pm 1 SEM. from this population decreased with increasing rate of glyphosate (0.0 to $\left.0.84 \mathrm{~kg} \cdot \mathrm{ha}^{-1}\right) 14$ DAT (Figure 3). Nearly all plants survived the $0.05 \mathrm{~kg} \cdot \mathrm{ha}^{-1}$ application rate, but $20 \%$ to $25 \%$ of the sprayed plants succumbed to the 0.32 and $0.53 \mathrm{~kg} \cdot \mathrm{ha}^{-1}$ treatments, while the highest rate of glyphosate caused death to nearly $65 \%$ of the seedlings. Thus at the highest level of glyphosate nearly $40 \%$ of the plants treated showed re-growth and an ability to survive. The $\mathrm{LD}_{50}$ (lethal dose) value determined on this Palmer amaranth population (Washington County, MS) sprayed with several glyphosate rates (0 to 0.84 $\mathrm{kg} \cdot \mathrm{ha}^{-1}$ ), 14 DAT was $0.75 \mathrm{~kg} \cdot \mathrm{ha}^{-1}$ (Figure 4). $\mathrm{LD}_{50}$ values of glyphosate resistant and susceptible Palmer amaranth have been shown to be $\sim 2$-fold higher in field-grown versus greenhouse-grown plants [3]. $\mathrm{LD}_{50}$ values of susceptible Palmer amaranth biotypes in Arkansas ranged from 0.024 to $0.035 \mathrm{~kg} \cdot \mathrm{ha}^{-1}$ glyphosate and one resistant biotype had an $\mathrm{LD}_{50}$ of $2.82 \mathrm{~kg} \cdot \mathrm{ha}^{-1}$ when greenhouse experiments were conducted [29]. This reported $\mathrm{LD}_{50}$ value range for susceptible plants is 20 to 30 -fold lower than found in the present study on this weed, which was tested as a population. The $\mathrm{LD}_{50}$ for the population in the present study was nearly 4 -fold lower

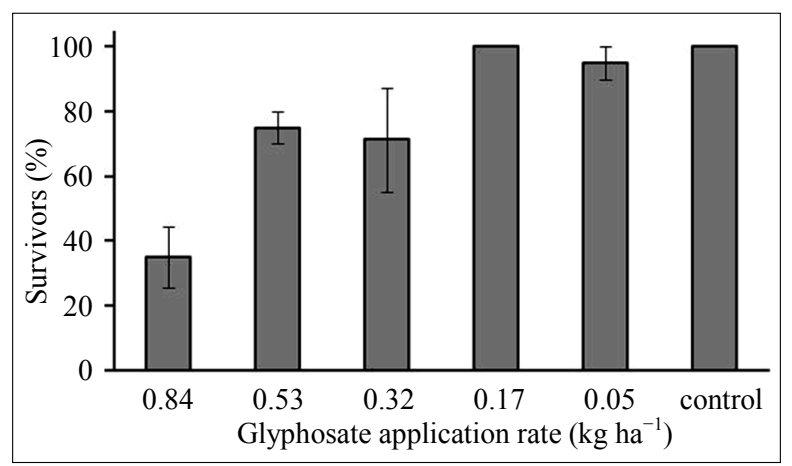

Figure 3. Percentage of Palmer amaranth plants from a population, surviving various glyphosate spray applications $\left(0.0\right.$ to $\left.0.84 \mathrm{~kg} \cdot \mathrm{ha}^{-1}\right), 14 \mathrm{DAT}$. Error bars represent \pm 1 SEM.

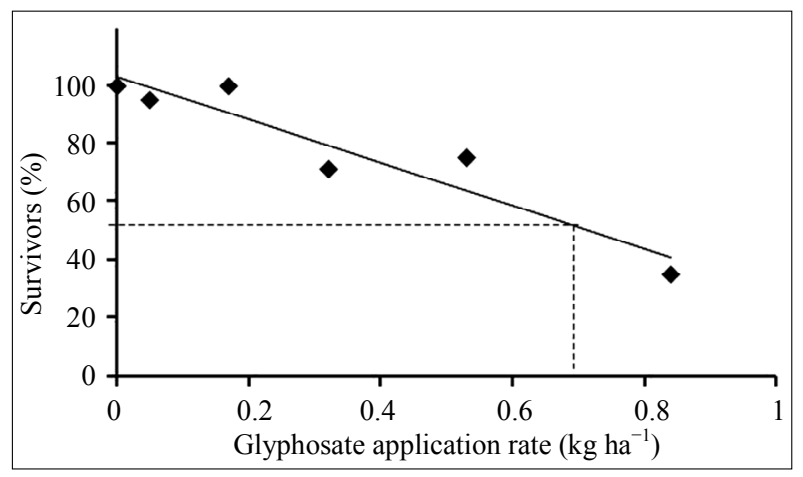

Figure 4. $\mathrm{LD}_{50}$ determination of a Palmer amaranth population sprayed with various glyphosate rates $(0.0$ to 0.84 $\left.\mathrm{kg} \cdot \mathrm{ha}^{-1}\right), 14$ DAT. 
than for the resistant biotype from Arkansas [29]. The population in the present study was not separated into susceptible and resistant groups for $\mathrm{LD}_{50}$ determinations, which would have resulted in lower and higher $\mathrm{LD}_{50}$ values for the susceptible and resistant groups, respectively. Furthermore, high purity glyphosate (without the influence of adjuvants/surfactants) was used, whereas most reports have determined $\mathrm{LD}_{50}$ values after spraying with commercial formulations of glyphosate. Thus, it is difficult to compare the degree of resistance due to differences in experimental and growth conditions.

Growth (fresh weight and dry weight accumulation) of the Washington County population of A. palmeri seedlings, was compared 14 DAT after spray application of glyphosate at various rates $\left(0.0\right.$ to $\left.0.84 \mathrm{~kg} \cdot \mathrm{ha}^{-1}\right)$ (Figure 5). Fresh and dry weight data support the general trend, that increasing glyphosate application reduces growth. There was a significant decrease in fresh and dry weight accumulation in the range of glyphosate treatments between 0.17 and $0.32 \mathrm{~kg} \cdot \mathrm{ha}^{-1}$. This effect was also observed in the health rating (Figure 2), but is not as prominent in plants surviving these treatments (Figure 3). Although this treatment range $\left(0.17\right.$ and $\left.0.32 \mathrm{~kg} \cdot \mathrm{ha}^{-1}\right)$ caused strong health (injury) and growth effects, all plants were not killed.

\subsection{Tests with Cloned Plants Selected from the Population}

When leaf discs of the cloned Palmer amaranth plants from this population were bioassayed for resistance to glyphosate, qualitative ratings over a time course revealed a range of tolerance (Figure 6). Using visual injury ratings assignments: $10=$ good health to $0=$ total lack of pigment) the bioassays demonstrated that some individual plants were very susceptible to glyphosate while others were moderately tolerant or resistant (Table

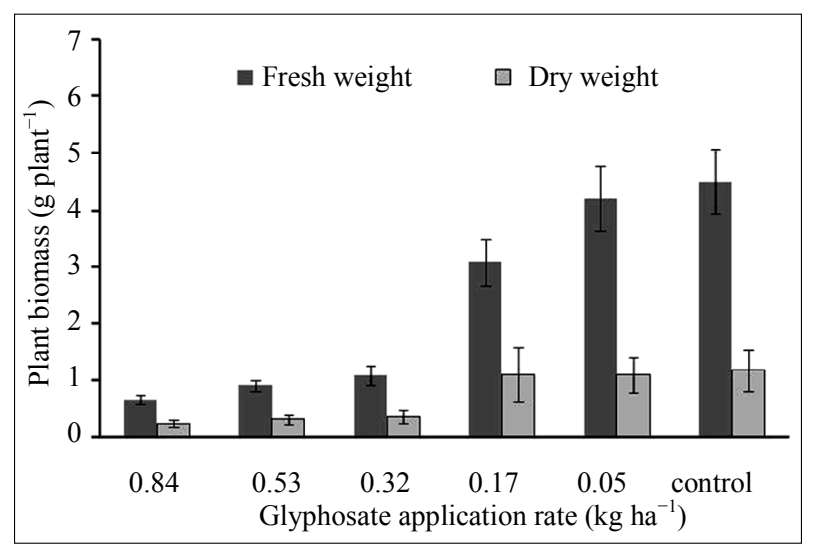

Figure 5. Growth (fresh weight and dry weight accumulation) of a population of $A$. palmeri seedlings, 14 DAT after spray application of glyphosate at various rates $(0.0$ to 0.84 $\left.\mathbf{k g} \cdot \mathrm{ha}^{-1}\right)$. Error bars represent \pm 1 SEM.
1). Comparison of the resistance ratings (Table 1) shows that a glyphosate-resistant positive control (G2 clone; high EPSPS copy number) from another Washington county population [21] was more resistant than any other individuals tested. Based on the results after exposure to $1 \mathrm{mM}$ glyphosate for $96 \mathrm{~h}$, the WC clones can be ranked

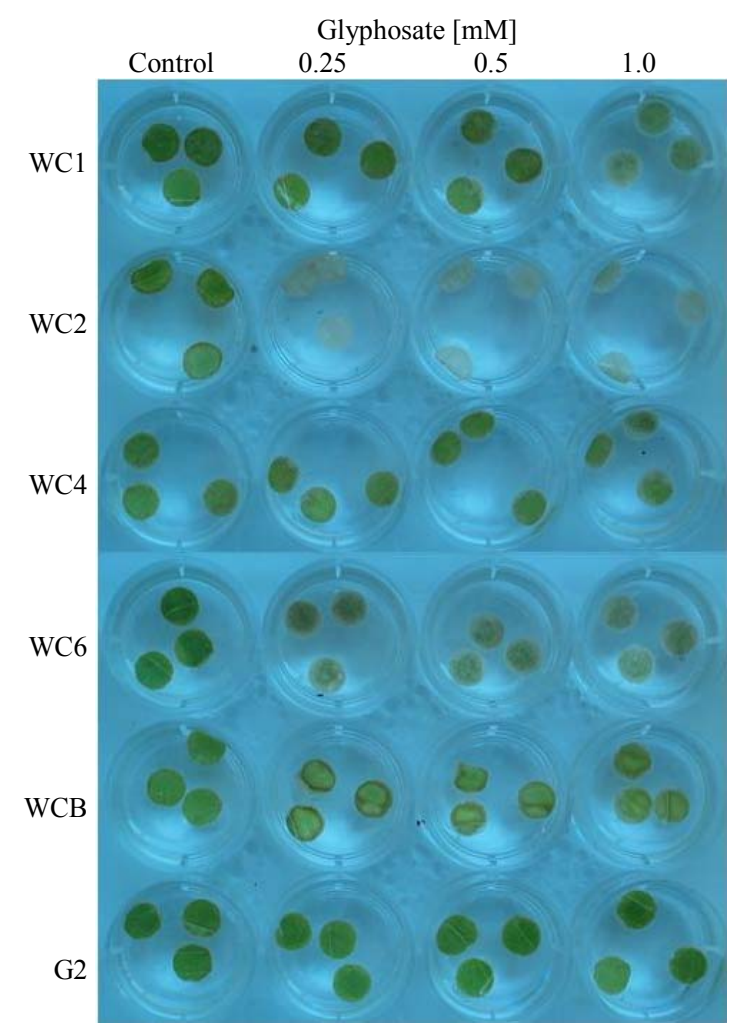

Figure 6. Example of injury caused by increasing glyphosate concentration on leaf disks of selected Palmer amaranth clones in a bioassay, 96 HAT. Bioassays were conducted at $22^{\circ} \mathrm{C}$ and continuous light $\left(150 \mu \mathrm{Em}^{-2} \cdot \mathrm{s}^{-1}\right)$. Disks were assigned a visual rating from 0 (high injury, mortality) to 10 (no injury).

Table 1. Leaf disc health ratings in a bioassay of selected cloned Palmer amaranth plants from a Washington County, MS population, over a $96 \mathrm{~h}$ time course during exposure to glyphosate.

\begin{tabular}{ccccc}
\hline \multicolumn{5}{c}{ Glyphosate $(1 \mathrm{mM})$} \\
HAT & $24 \mathrm{~h}$ & $48 \mathrm{~h}$ & $72 \mathrm{~h}$ & $96 \mathrm{~h}$ \\
WC1 & 9.6 & 9.6 & 8.0 & 5.5 \\
WC2 & 9.5 & 9.5 & 1.0 & 0 \\
WC4 & 10.0 & 10.0 & 8.0 & 7.7 \\
WC6 & 9.6 & 9.6 & 6.0 & 1.0 \\
WCB & 9.6 & 9.6 & 7.5 & 7.5 \\
G2 & 9.6 & 9.6 & 9.5 & 9.3 \\
\hline
\end{tabular}

Health rating 10 (good health) to 0 (total chlorosis). 
in order of decreasing resistance to glyphosate: $\mathrm{WCB}=$ WC4 $>$ WC1 $>>>$ WC6 $>$ WC2. Confirmation of the visual rating assignments was achieved by quantitative analysis of chlorophyll content in glyphosate-treated leaf discs from the above bioassay at $96 \mathrm{~h}$ after treatment. The quantitative data substantiated the qualitative findings, i.e., a wide variation in tolerance to glyphosate exists in these clones from the WC population (Figure 7). Increases in shikimate levels generally occur in glyphosate susceptible plants after treatment with the herbicide [16]. Shikimate accumulation in leaf discs of several cloned individual A. palmeri plants exposed to various concentrations of glyphosate and light $\left(150 \mu \mathrm{E} \cdot \mathrm{m}^{-2} \cdot \mathrm{s}^{-1}\right)$ in an assay, $24 \mathrm{~h}$ after exposure to glyphosate at several concentrations exhibited differences in the resistant and susceptible plants (Figure 8). All of the resistant clones

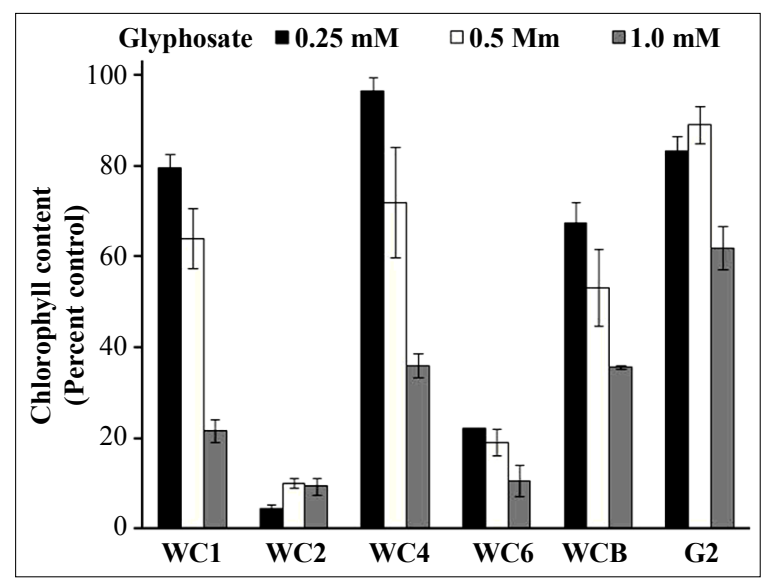

Figure 7. Chlorophyll content of leaf discs in a bioassay of cloned Palmer amaranth plants after exposure to glyphosate at several concentrations, 96 HAT. Error bars represent \pm 1 SEM.

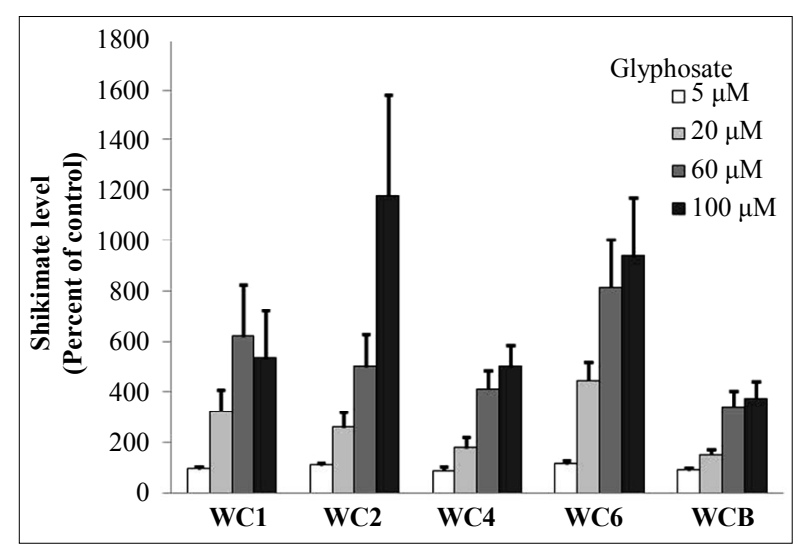

Figure 8. Shikimate accumulation in leaf discs of several cloned individual $A$. palmeri plants exposed to several concentrations of glyphosate and light $\left(150 \mu \mathrm{E} \cdot \mathrm{m}^{-2} \cdot \mathrm{s}^{-1}\right)$ in a bioassay, $24 \mathrm{~h}$ after exposure. Leaf discs were exposed to high purity glyphosate $(99 \%)$ at 0 to $100 \mu \mathrm{M}$. Error bars represent \pm 1 SEM.
(WC1, WC4, WCB; determined via bioassay) accumulated some shikimate, but at lower levels than the susceptible clones (WC2 and WC6) after exposure to glyphosate. In horseweed, glyphosate has been suggested to be partially excluded from the plastids of resistant plants thus resulting in lower EPSPS inhibition than in susceptible plant tissues, but still causing elevated shikimate levels after herbicide exposure [30].

The varying level of resistance within this Palmer amaranth population was further verified using these selected individual, cloned plants after application of two rates of glyphosate $\left(0.32\right.$ and $\left.0.84 \mathrm{~kg} \cdot \mathrm{ha}^{-1}\right)$ (Figure 9). Results supported the bioassay data of cloned plants (Table 1 and Figure 6) and data from the population tests, i.e., some plants are very susceptible while others are resistant.

\subsection{Copy Number}

Q-PCR analysis of the cloned set of these Palmer amaranth plants showed that EPSPS copy number was not elevated relative to a known glyphosate susceptible Palmer amaranth population tested previously [22]. The ALS gene was used as a low copy number control gene since it possesses known mono-genetic inheritance in other species of Amaranthus [28]. Therefore, the fact that a range of tolerance to glyphosate was exhibited in these cloned individuals (bioassayed against various glyphosate concentrations or treated with spray applications of glyphosate at several rates), coupled with a lack of elevated copy number demonstrates that high copy number is not an operative mechanism here and strongly suggests that other resistance mechanism(s) are present. Altered target-site (Pro 106) and non-target-site (translocation) mechanisms have recently been found in a population of a related Amaranthus species (tall waterhemp; Amaranthus tuberculatus) [31]. Thus similar mechanisms

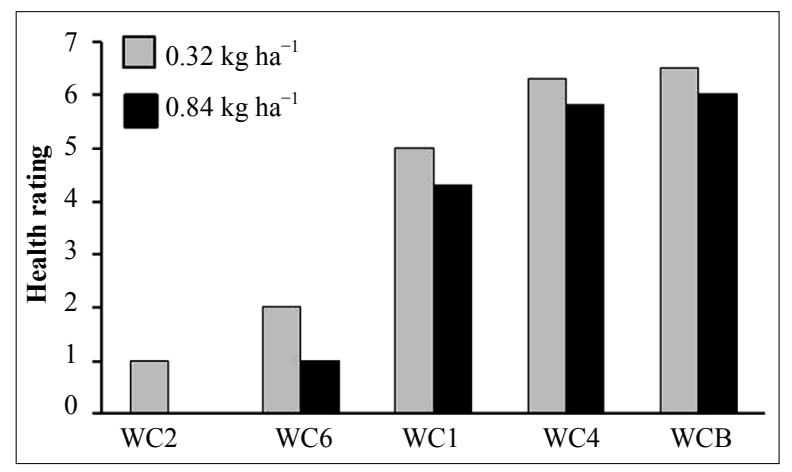

Figure 9. Effects of spray application of glyphosate at two rates $\left(0.32\right.$ and $\left.0.84 \mathrm{~kg} \cdot \mathrm{ha}^{-1}\right)$ on a set of cloned Palmer amaranth plants, 14 DAT. Rating scale: $7=$ no effect, $6=$ slight wilting, $5=$ moderate wilting, $4=$ severe wilting, $3=$ slight necrosis, 2 moderate necrosis, $1=$ severe necrosis, $\mathbf{0}=$ death/mortality. 
could possibly be operative in the Palmer amaranth population studied here since these two species are closely related and have been shown to hybridize [32,33].

Several glyphosate resistance mechanisms in weeds have been reported, including: reduced translocation [34], altered EPSPS sequence [34], and sequestration [35]. We are in the process of examining uptake and translocation of glyphosate in the WC cloned Palmer amaranth biotypes tested here, as well as EPSPS target site sequence substitution and expression. A point mutation in the EPSPS gene and reduced glyphosate translocation were responsible for glyphosate resistance in a ryegrass population from South Africa [36]. Recently, certain ryegrass populations were shown to contain multiple glyphosate resistance mechanisms [37,38]. An Italian ryegrass biotype exhibited a 23 -fold increase in resistance with only a 6-fold increase in EPSPS activity, suggesting that elevated EPSPS gene copy number may not be the only resistance mechanism $[39,40]$. It has been pointed out that investigations of large populations of out-crossing species (Palmer amaranth is one) can reveal broad trends in resistance mechanisms, but mechanisms occurring at low frequency may be overlooked [41]. Overall, the herbicide resistance mechanism(s) of individual plants from a given population is rarely investigated.

Within a given plant population, such as the Palmer amaranth population studied here, a range of herbicide tolerance and multiple mechanisms of tolerance/resistance to a single herbicide (glyphosate) may exist. Information on the degree of tolerance and tolerance mechanisms may remain obscure when only a single resistance mechanism is investigated, or when plants of a population are not examined as subgroups or individuals. Several of the most resistant and susceptible plants from this population were chosen and propagated by cloning. Some plants that survived whole plant spray applications at high levels of glyphosate (resistant) were selected and cloned, while susceptible plants were killed. The non-destructive method of leaf disc bioassays (versus herbicide spray application) allowed parent plant survival, thus enabling selection of both susceptible and more resistant plants for continued study and propagation. Maintenance of these clone lines allowed investigations of resistance mechanisms by eliminating transfer of genetic traits through crossing. Palmer amaranth plants are either male or female (dioecious) and resistance traits can spread by pollen transfer in these cross-pollinating plants. Palmer amaranth has also been shown to cross with waterhemp (Amaranthus rudis), thereby transferring herbicide resistance traits [33].

\section{Conclusions}

These results are important because they demonstrate a wide diversity of individuals within a given weed population that can obfuscate the characterization of herbicide resistance mechanisms. Populations of weeds generally lack genetic homogeneity. However, a given population can be selectively classified and grouped using bioassays for herbicide susceptibility/tolerance, herbicide spray application, seed germination in herbicide solutions, etc., in order to divide a population into more homogeneous groups. For example, selection for resistance and susceptibility to the herbicide sulfometuron was achieved by seed germination in agar containing the herbicide [41].

The seeds of the population used in the present study were collected in 2000 , which was about five years prior to the first report of resistance to glyphosate in Palmer amaranth [3], and about 10 years before resistance was defined as elevated EPSPS gene copy number in this weed [18]. The utilization of survivors from glyphosate spray applications and non-destructive bioassays, enabled the selection of a set of individual plants that possessed a range of herbicide tolerance to glyphosate. This was followed by cloning of these plants so that long-term testing could be pursued.

Several studies related to glyphosate resistance and elevated EPSPS copy number in Palmer amaranth and related species are available $[18,22,31,42,43]$. Elevated EPSPS copy number has also been identified as a glyphosate resistance mechanism in ryegrass [40]. However, the absence of the elevated copy number trait in these cloned plants, coupled with relatively high tolerance of some individuals, suggests that other tolerance mechanisms are operative. Similar results were found when another susceptible Palmer amaranth population (C3; non-elevated copy number), examined on an individual plant basis, showed a range of tolerance to glyphosate [22]. The most resistant plants (WC4 and WCB) exhibited resistance comparable to the most glyphosate-tolerant clones of the susceptible (C3) population [21,22]. Indeed, results of this latter study led to the investigation of the present research on this 2000 population. Future work is needed to determine if possible differences in glyphosate uptake/translocation, sequestration, or altered target site (EPSPS) or EPSPS expression contribute to the variation in responses to glyphosate demonstrated by these individually characterized plants. Metabolism is also a possible resistance mechanism, but as yet has not been found in glyphosate resistance studies on several weeds, e.g., horseweed [30], ryegrass [44,45] and goosegrass [46].

\section{Acknowledgements}

The authors would like to acknowledge and thank Robin H. Jordan for the excellent technical expertise during the course of this project. 


\section{REFERENCES}

[1] I. Heap, "International Survey of Herbicide-Resistant Weeds," 2013. http://www.weedscience.org/in.asp

[2] Anonymous, "New Report Reveals Dramatic Rise in Pesticide Use on Genetically Engineered (GE) Crops Due to the Spread of Resistant Weeds," 2009.

http://wwwprnewswire.com/news-release

[3] S. Culpepper, T. L. Grey, W. K. Vencill, J. M. Kichler, T. M. Webster, S. M. Brown, A. C. York, J. W. Davis and W. W. Hanna, "Glyphosate-Resistant Palmer Amaranth (Amaranthus palmeri) Confirmed in Georgia," Weed Science, Vol. 54, No. 4, 2006, pp. 620-626. http://dx.doi.org/10.1614/WS-06-001R.1

[4] R. C. Scott, L. E. Steckel, K. L. Smith, T. Mueller, L. R. Oliver and J. Norsworthy, "Glyphosate-Resistant Palmer Amaranth inTennessee and Arkansas," Proceedings of the 60th Southern Weed Science Society, Nashville, 22-24 January 2007, p. 226.

[5] C. York, J. R. Whitaker, A. S. Culpepper and C. L. Main, "Glyphosate-Resistant Palmer Amaranth in the Southeastern United States," Proceedings of the Southern Weed Science Society, Vol. 60, 2007, p. 225.

[6] T. M. Webster, "Weed Survey-Southern States: Broadleaf Crops Subsection," Proceedings of the Southern Weed Science Society, Vol. 58, 2005, pp. 291-294.

[7] M. J. Horak and T. M. Loughin, "Growth Analysis of Four Amaranthus Species," Weed Science, Vol. 48, No. 3, 2000, pp. 347-355.

http://dx.doi.org/10.1614/0043-1745(2000)048[0347:GA OFAS]2.0.CO;2

[8] N. Bensch, M. J. Horak and D. Peterson, "Interference of Redroot Pigweed (Amaranthus retroflexus), Palmer Amaranth (A. palmeri), and Common Waterhemp (A. rudis) in Soybean," Weed Science, Vol. 51, No. 1, 2003, pp. 37-43. http://dx.doi.org/10.1614/0043-1745(2003)051[0037:IOR PAR]2.0.CO;2

[9] A. Sellers, R. J. Smeda, W. G. Johnson, A. J. Kendig and M. R. Ellersieck, "Comparative Growth of Six Amaranthus Species in Missouri," Weed Science, Vol. 51, No. 3, 2003, pp. 329-333.

http://dx.doi.org/10.1614/0043-1745(2003)051[0329:CG OSAS $72.0 . \mathrm{CO} ; 2$

[10] S. Culpepper, A. W. MacRae, A. C. York and J. Kichler, "Managing Glyphosate-Resistant Palmer Amaranth in Conventional and Strip-Till Roundup Ready Cotton," Proceedings of the Southern Weed Science Society, Vol. 61, 2008, p. 62.

[11] S. Culpepper, A. C. York, J. M. Kichler and A. W. MacRae, "Glyphosate-Resistant Palmer Amaranth Response to Weed Management Programs in Roundup Ready and Liberty Link Cotton," Proceedings of the Beltwide Cotton Conference, Nashville, 10 January 2008, pp. 1689-1690.

[12] J. R. Whitaker, "Distribution, Biology, and Management of Glyphosate Resistant Palmer Amaranth in North Carolina," Ph.D. Dissertation, North Carolina State University, Raleigh, 2009.

http://repository.lib.ncsu.edu/ir/bitstream/1840.16/3130/1/ etd.pdf
[13] H. C. Steinrücken and N. Amrhein, "The Herbicide Glyphosate Is a Potent Inhibitor of 5-Enolpyruvyl-Shikimic Acid-3-Phosphate Synthase," Biochemical and Biophysical Research Communications, Vol. 94, No. 4, 1980, pp. 1207-1212.

http://dx.doi.org/10.1016/0006-291X(80)90547-1

[14] J. E. Franz, M. K. Mao and J. A. Sikorski, "Glyphosate's Molecular Mode of Action," In: Glyphosate: A Unique Global Herbicide, American Chemical Society, Washington DC, 1997, pp. 521-615.

[15] K. J. Gruys and J. A. Sikorski, "Inhibitors of Tryptophan, Phenylalanine and Tyrosine Biosynthesis as Herbicides," In: B. K. Singh, Ed., Plant Amino Acids: Biochemistry and Biotechnology, CRC Press, Boca Raton, 1999, pp. 357-384.

[16] N. Amrhein, B. Deus, P. Gehrke and H. C. Steinrüchen, "The Site of the Inhibition of the Shikimate Pathway by Glyphosate. II. Interference of Glyphosate with Chorismate Formation in Vivo and in Vitro," Plant Physiology, Vol. 66, No. 5, 1980, pp. 830-834.

http://dx.doi.org/10.1104/pp.66.5.830

[17] K. M. Herrmann, "The Shikimate Pathway as an Entry to Aromatic Secondary Metabolism," Plant Physiology, Vol. 107, No. 1, 1995, pp. 7-12. http://dx.doi.org/10.1104/pp.107.1.7

[18] T. A. Gaines, W. Zhang, D. Wang, B. Bukun, S. T. Chis-holm, D. L. Shaner, S. J. Nissen, W. L. Patzoldt, P. J. Tranel, A. S. Culpepper, T. L. Grey, T. M. Webster, W. K. Vencill, R. D. Sammons, J. Jiang, C. Preston, J. E. Leach and P. Westra, "Gene Amplification Confers Glyphosate Resistance in Amaranthus palmeri," Proceedings of the National Academy of Sciences, Vol. 107, No. 3, 2010, pp. 1029-1034. http://dx.doi.org/10.1073/pnas.0906649107

[19] Sosnoskie, L. M., T. M. Webster, A. S. Culpepper and J. Kichler, "The Biology and Ecology of Palmer amaranth: Implications for Control," 2011.

http://www.caes.uga.edu/applications/publications/files/p df/C\%201000_1.PDF

[20] D. L. Shaner, R. B. Lindenmeyer and M. H. Ostlie, "What Have the Mechanisms of Resistance to Glyphosate Taught Us?" Pest Management Science, Vol. 68, No. 1, 2011, pp. 3-9.

[21] R. E. Hoagland, R. H. Jordan and N. D. Teaster, "Bioassay and Characterization of Several Palmer Amaranth (Amaranthus palmeri) Biotypes with Varying Tolerances to Glyphosate," American Journal of Plant Sciences, Vol. 4, No. 5, 2013, pp. 1029-1037. http://dx.doi.org/10.4236/ajps.2013.45127

[22] N. D. Teaster and R. E. Hoagland, "Characterization of Glyphosate Resistance in Cloned Amaranthus palmeri Plants," Weed Biology and Management, 2013, in Press.

[23] J. D. Barnes, L. Balaguer, E. Manriques, S. Elvira and A. W. Davison, "A Reappraisal of the Use of DMSO for the Extraction and Determination of Chlorophylls a and b in Lichens and Higher Plants," Environmental and Experimental Botany, Vol. 32, No. 2, 1992, pp. 85-100. http://dx.doi.org/10.1016/0098-8472(92)90034-Y

[24] J. D. Hiscox and G. F. Israelstam. "A Method for the Extraction of Chlorophyll from Leaf Tissue without 
Maceration," Canadian Journal of Botany, Vol. 57, No. 12, 1979, pp. 1332-1334. http://dx.doi.org/10.1139/b79-163

[25] T. Evans, J. Song and P. E. Jameson, "Micro-Scale Chlorophyll Analysis and Developmental Expression of a Cytokinin Oxidase/Dehydrogenase Gene during Leaf Development and Senescence," Plant Growth Regulation, Vol. 66, No. 1, 2012, pp. 95-99. http://dx.doi.org/10.1007/s10725-011-9627-5

[26] D. L. Shaner, T. Nadler-Hassar, W. B. Henry and C. H. Koger, "A Rapid in Vivo Shikimate Accumulation Assay with Excised Leaf Discs," Weed Science, Vol. 53, No. 6, 2005, pp. 769-774.doi.org/10.1614/WS-05-009R.1

[27] K. J. Livak and T. D. Schmittgen, "Analysis of Relative Gene Expression Data using Real-Time Quantitative PCR and the $2^{-\Delta \Delta C T}$ Method," Methods, Vol. 25, No. 4, 2001, pp. 402-408. http://dx.doi.org/10.1006/meth.2001.1262

[28] F. Trucco, M. R. Jeschke, A. L. Rayburn and P. J. Tranel, "Promiscuity in Weedy Amaranths: High Frequency of Tall Waterhemp (Amaranthus tuberculatus) x Smooth Pigweed (A. hybridus) Hybridization under Field Conditions," Weed Science, Vol. 53, No. 1, 2005, pp. 46-54. http://dx.doi.org/10.1614/WS-04-103R

[29] J. K. Norsworthy, G. M. Griffith, R. C. Scott, K. L. Smith and L. R. Oliver, "Confirmation and Control of Glyphosate Palmer amaranth (Amaranthus palmeri) in Arkansas," Weed Technology, Vol. 22, No. 1, 2008, pp. 108113. http://dx.doi.org/10.1614/WT-07-128.1

[30] P. C. C. Feng, M. Tran, T. Chiu, R. D. Sammons, G. R. Heck and C. A. CaJacob, "Investigations into GlyphosateResistant Horseweed (Conyza canadensis): Retention, Uptake, Translocation, and Metabolism," Weed Science, Vol. 52, No. 4, 2004, 498-505. http://dx.doi.org/10.1614/WS-03-137R

[31] V. K. Nandula, J. D. Ray, D. N. Ribeiro, Z. Pan and K. N. Reddy, "Glyphosate Resistance in Tall Waterhemp (Amaranthus tuberculatus) from Mississippi Is Due to Both Altered Target-Site and Nontarget-Site Mechanisms. Weed Science, Vol. 61, No. 3, 2013, pp. 374-383. http://dx.doi.org/10.1614/WS-D-12-00155.1

[32] A. S. Franssen, D. Z. Skinner, K. Al-Khatib, M. J. Horak and P. A. Kulakow, "Interspecific Hybridization and Gene Flow of ALS Resistance in Amaranthus Species," Weed Science, Vol. 49, No. 5, 2001, pp. 598-606. http://dx.doi.org/10.1614/0043-1745(2001)049[0598:IHA $\mathrm{GFO} 2.0 . \mathrm{CO} ; 2$

[33] D. K. Wetzel, M. J. Horak, D. Z. Skinner and P. A. Kulakow, "Transferal of Herbicide Resistance Traits from Amarathus palmerito Amaranthus rudis," Weed Science, Vol. 47, No. 5, 1999, pp. 538-543.

[34] S. B. Powles and C. Preston, "Evolved Glyphosate Resistance in Plants: Biochemical and Genetic Basis of Resistance," Weed Technology,Vol. 20, No. 2, 2006, pp. 282-289. http://dx.doi.org/10.1614/WT-04-142R.1

[35] X. Ge, D. A. d'Avignon, J. J. H. Ackerman and R. D. Sammons, "Rapid Vacuolar Sequestration: the Horseweed Glyphosate Resistance Mechanism," Pest Management Science, Vol. 66, No. 4, 2010, pp. 345-348.

[36] Q. Yu, A. Cairns and S. Powles, "Glyphosate, Paraquat and ACCase Multiple Herbicide Resistance Evolved in a Lolium rigidumBiotype," Planta, Vol. 225, No. 2, 2007, pp. 499-513. http://dx.doi.org/10.1007/s00425-006-0364-3

[37] V. K. Nandula, K. N. Reddy, D. H. Poston, A. M. Rimando and S. O. Duke, "Glyphosate Tolerance Mechanism in Italian Ryegrass (Lolium multiflorum) from Mississippi," Weed Science, Vol. 56, No. 3, 2008, pp. 344-349. http://dx.doi.org/10.1614/WS-07-115.1

[38] A. Perez-Jones, K. W. Park, N. Polge, J. Colquhoun and C. A. Mallory-Smith, "Investigating the Mechanisms of Glyphosate Resistance in Lolium multiflorum," Planta, Vol. 226, No. 2, 2007, pp. 395-404. http://dx.doi.org/10.1007/s00425-007-0490-6

[39] J. W. Dickson, R. C. Scott, N. R. Burgos, R. A. Salas and K. L. Smith, "Confirmation of Glyphosate-Resistant Italian Ryegrass (Lolium perenne ssp. multiflorum) in $\mathrm{Ar}$ kansas," Weed Technology, Vol. 25, No. 4, 2011, pp. 674 679. http://dx.doi.org/10.1614/WT-D-11-00040.1

[40] R. A. Salas, F. E. Dayan, Z. Pan, S. B. Watson, J. W. Dickson, R. C. Scott and N. R. Burgos, "EPSPS Gene Amplification in Glyphosate-Resistant Italian Ryegrass (Lolium perennespp. multiflorum) from Arkansas," Pest Management Science, Vol. 68, No. 9, 2012, pp. 12231230. http://dx.doi.org/10.1002/ps.3342

[41] M. W. M. Burnet, J. T. Christopher, J. A. M. Holtum and S. B. Powles, "Identification of Two Mechanisms of Sulfonylurea Resistance within One Population of Rigid Ryegrass (Lolium rigidum) Using a Selective Germination Medium," Weed Science, Vol. 42, No. 3, 1994, pp. 468-473. http://wssaabstracts.com/public/4/abstract-85,html

[42] D. A. Giacomini, S. Ward, T. A. Gaines and P. Westra, "Inheritance of EPSPS Gene Amplification in Palmer Amaranth," Proceedings of the Weed Science Society of America, Vol. 53, No. 85. 2011.

[43] A. Chandi, S. R. Milla-Lewis, D. Giacomini, P. Westra, C. Preston, D. L. Jordan, A. C. York, J. D. Burton and J. R. Whitaker, "Inheritance of Evolved Glyphosate Resistance in a North Carolina Palmer Amaranth (Amaranthus palmeri) Biotype," International Journal of Agronomy, Vol. 2012, No. 2012, 2012, pp. 1-7. http://dx.doi.org/10.1155/2012/176108

[44] P. C. C. Feng, J. E. Pratley and J. A. Bohn, "Resistance to Glyphosate in Lolium rigidum. II. Uptake, Translocation and Metabolism," Weed Science, Vol. 47, No. 4, 1999, pp. 412-415.

[45] D. F. Lorraine-Colwill, S. B. Powles, T. R. Hawkes, P. H. Hollinshead, S. A. J. Warner and C. Preston, "Investigations into the Mechanism of Glyphosate Resistance in Lolium rigidum," Pesticide Biochemistry and Physiology, Vol. 74, No. 2, 2003, pp. 62-72.

[46] M. Tran, S. Baerson, R. Brinker, L. Casagrande, M. Faletti, Y. Feng, M. Nemeth, T. Reynolds, D. Rodriguez, D. Shaffer, D. Stalker, N. Taylor, Y. Teng and G. Dill, "Characterization of Glyphosate Resistant Eleusine indica Biotypes from Malaysia," Proceedings of the 17th AsianPacific Weed Science Society Conference, Bangkok, 22-27 November 1999, pp. 527-536. 